\begin{tabular}{|c|c|c|}
\hline PORT SAID ENGINEERING RESEARCH JOURNAL \\
Port Said University - Faculty of Engineering \\
Volume 17 No. 2 September 2013 pp: 136-146
\end{tabular}

\title{
Reducing Settlement Using Piled Raft for Neighboring Foundations in Port-Said
}

\author{
M. Mohamedien ${ }^{1}$, M. El Gendy ${ }^{2}$, I. ELArabi ${ }^{2}$, M. El Azab ${ }^{2}$ and A. Moubarak ${ }^{1}$
}

\begin{abstract}
The problems of build ing settlements in Port-Said area have been a great concern in recent years. Damages occur in buildings due to urban development that requires high rise structures to accommodate these extensions. Raft has been used for many new buildings in Port-Said. Soft to firm clay layers extends down to depths reaching $60 \mathrm{~m}$ under the ground surface. This paper studies the effect of constructing new building beside an existing one. Piled raft has been studied as settlement reducer and thus to be used as a foundation system in the new building. The typical soil stratification and properties in Port-Said zone are considered in this study. Parametric study is carried out to examine influence of new piled raft variables on the existing building. It has proved that the use of piled raft reduces considerably settlement under the existing building.
\end{abstract}

KEYWORDS: Raft, piled raft, soil-structure interaction, foundation, settlement.

\section{INTRODUCTION}

Port-Said lies on the eastern side of the Nile Delta at the north end of the Suez Canal on the Mediterranean Sea.

Most dry land in Port-Said has been reclaimed except for a narrow beach which separated Lake Manzala from the sea. This narrow beach was subdivided into several zones and was studied by Golder Associates (1979). The study investigated clearly the soil layering and stratification down to $60 \mathrm{~m}$ below the ground surface. The investigation showed that Port-Said area contains clay layers starting from about $12 \mathrm{~m}$ under the ground surface to down to $50 \mathrm{~m}$. The same clay layers are also found in the old area of the city. Natural soil deposits having extended clay layers causes settlement problems as observed in Port-Said area. Raft foundations are used to reduce settlement problems observed under many buildings in Port-Said. Thus, it is necessary to study another suitable foundation system such as piled raft.

Analyzing piled raft is a complex task because of the three-dimensional nature of the problem. Main capabilities that must be considered in the analysis are; interaction between all piles, raft and soil elements; accounting for the actual loading and geometry of pile foundations; representing a realistic nonlinear soil model in the analysis.

Considering all these factors require great experience and effort. Analysis of piled raft foundations is illustrated in literatures [2] to [15]. Accounting for the above mentioned factors, the proposed piled raft on Port-Said has been analyzed by modules of compressibility method for elastic raft on layered subsoil model.

Parameters studied in the parametric study are chosen to cover most of the possible variables that affect behavior of piled raft.

\footnotetext{
${ }^{1}$ Faculty of Engineering, Suez Canal University, Egypt.
}

${ }^{2}$ Faculty of Engineering, Port-Said University, Egypt.
This paper illustrates the effect of using piled raft as a foundation system in the new building $B_{R}$ to reduce differential settlement of the existing building $B_{L}$. To achieve this task, typical soil stratification and properties that exist in Port- Said are considered in the analysis.

A parametric study is carried out to assess the effect of the different foundation parameters and get optimal foundation dimensions. Results of this research would form a base for piled raft design guidelines in Port-Said, where piled raft never been used in this area.

\section{MATHEMATICAL MODELING}

Numerical study of this research is carried out by commercial program ELPLA [8], which can analyze piled raft and raft using different subsoil models. In the analysis, the raft is analyzed by the finite element method.

Piled raft is treated as a rigid member having a uniform settlement on its nodes. Soil is modeled as a three dimensional continuum medium. Nonlinear analysis of pile foundation is taken into account using hyperbolic function. Theoretical bases of soil models and methods in ELPLA [8] are well documented by EL Gendy et al. (2006), EL Gendy (2007 a, b).

\section{SOIL PROPERTIES}

The study presented in this paper is carried accounting for the soil data in reclaimed zones as source data. This source data has been based upon the extensive geotechnical study performed by Golder Associates (1979). According to several investigated cases down to $60 \mathrm{~m}$ under the ground surface for 6 zones in Port-Said as shown in Figure (1), surface soil conditions are relatively uniform but in some places the ground surface is underlain by fill. The whole areas have a thin layer of very soft surface clay with an average thickness of $0.2 \mathrm{~m}$ in the northern part of the zones to $2 \mathrm{~m}$ thick in the south. Below the surface clay layer there is compact dense fine 
sand with an average thickness of about $7 \mathrm{~m}$, sand grades downward through a transition zone into firm clay to 12 $\mathrm{m}$. A thick clay layer extends to an average depth of about $50 \mathrm{~m}$ below the ground surface, resting on basal deposits of hard clay and dense sand. In this paper soil data of zone 2, which are similar to the most of those exist in Port-Said, are considered. Zone 2 lies south the city. It contains the water treatment station, few apartment buildings, agricultural and industrial development areas. Figure (2) shows a main soil profile of Port-Said area. Figure (3) shows some photos of building damages resulting from adjacent constructions in Port-Said.

\subsection{Modulus of Compressibility}

Analysis of foundation using continuum model requires the modulus of compressibility of clay Es as a main soil parameter. Considering the available water content for clay layers from Golder Associates [1], these variables can be represented in general equations related to the depth. Reda [12] has determined the modulus of compressibility for each zone and verified it. It can be approximated it by the following linear relation:

$E_{s}=E_{s o}(1+0.06 z)$

Where:

$E_{s}$ : Modulus of compressibility, $\left(\mathrm{MN} / \mathrm{m}^{2}\right)$.

$E_{s o}$ : Initial modulus of compressibility,

$E_{s o}=2\left(\mathrm{MN} / \mathrm{m}^{2}\right)$ and

$z$ :Depth measured from the clay surface, $\mathrm{m}$.

\subsection{Groundwater}

Groundwater in Port-Said lies within $2 \mathrm{~m}$ from the ground surface. In this study the groundwater level is assumed to lie directly below the raft, where foundation level is considered at $1.9 \mathrm{~m}$.

\subsection{Typical Soil Profile and Soil Properties}

According to the soil stratification in zone 2, typical soil profile and soil properties used in the analysis are shown in Table 1.

\section{PARAMETRIC STUDY}

Piled raft is used as a settlement reducer. Thus, it is considered as a foundation system for the new building $B_{R}$.

\subsection{Raft -Raft Interaction [R-R]}

For the purpose of comparis on between results obtained from raft-piled raft interaction and those of raft-raft interaction, parametric study is carried out firstly for raftraft system, which studies the interaction between an existing building on a raft foundation and the construction of a new neighboring building on raft foundation also.

Considering the two build ings $B_{L}$ and $B_{R}$ are constructed on two rafts. Geometry and loads of the two rafts used in the analysis are shown in Figure (4).

Choosing rafts dimensions and load geometries depend on the typical residential building in Port-Said. Ranges of parametric study variables for raft-raft interaction analyses are listed in Table 2. For raft-raft analysis and raft-piled raft analysis, results are only obtained for foundation of dimensions $20 \times 20 \mathrm{~m}^{2}$ and the new building
$B_{R}$ loaded by $120 \mathrm{kN} / \mathrm{m}^{2}$, while the existing building $B_{L}$ was loaded by $50 \mathrm{kN} / \mathrm{m}^{2}$. Then, generalization factors are obtained for the other cases.

\subsection{Material Properties}

Raft and piled raft have the following material parameters:

Young's modulus $E_{b}=3.4 * 10^{7}\left(\mathrm{kN} / \mathrm{m}^{2}\right)$

Poisson's ratio $\quad v_{b}=0.2$ and

Unit weight $\quad \gamma_{b}=0$

While piles have the following material parameters:

Young's modulus $E_{b}=2.35 * 10^{7}\left(\mathrm{kN} / \mathrm{m}^{2}\right)$ and

Unit weight $\quad \gamma_{\mathrm{b}}=0$

\subsection{Results of Analysis}

\subsubsection{Settlement}

The settlement effect is expressed as a dimensionless settlement ratio rsc, which given by: $\mathrm{rsc}=\mathrm{Sc} / \mathrm{Smax}$. Where, $\mathrm{Sc}$ is the calculated settlement of the existing building (cm) and Smax is the maximum allowable settlement according to ECP (1995), which equals to $15 \mathrm{~cm}$.

Figures (5) to (8) show settlement ratio distribution along the common central axis of the two neighboring buildings. Raft thickness of the existing building $B_{L}$ equals $0.5 \mathrm{~m}$. Thickness of the new raft $B_{R}$ is variable to study its effect on settlement ratio of the existing building $B_{L}$. Thickness $T$ of the new raft $B_{R}$ ranged from $0.8 \mathrm{~m}$ to $1.5 \mathrm{~m}$. From these figures it can be observed that: increasing the raft thickness $T$ of the new building $B_{R}$ slightly decreases the differential settlement of the existing building $B_{L}$. Moreover, differential settlements of the existing building $B_{L}$ are inversely proportional to distance $D$ between the existing raft and the new one. Angular distortion of the existing building $B_{L}$ is ranged from $0.678 \%$ to $0.26 \%$ for distances $D$ equal 0.2 and $6 \mathrm{~m}$, respectively.

\subsubsection{Differential Settlement}

Figure (9) shows the calculated differential settlements between points $b$ and $g$ at the existing building $B_{L}$ as a dimensionless angular distortion ratio $\mathrm{r} \alpha, \mathrm{r} \alpha=\alpha \mathrm{o} / \alpha$ max. $\alpha$ o equals the calculated differential settlement of existing building $B_{L}$ and $\alpha \max$ is the maximum allowable differential settlement according to ECP (1995), which equals $1 / 500$.

It can be observed that; increasing the raft thickness $T$ of the new building $B_{R}$ slightly decreases the angular distortion ratio of the existing building $B_{L}$. The angular distortion ratio decreases from 1.875 to 1.7 , when the thickness $T$ ranged from $0.8 \mathrm{~m}$ to $1.5 \mathrm{~m}$ at $D$ equals $0.2 \mathrm{~m}$.

The separation distance $D$ is inversely proportional to the angular distortion ratio of the existing building $B_{L}$. The angular distortion ratio decreases from 1.7 to 0.65 for distances $D$ ranged between $0.2 \mathrm{~m}$ to $6 \mathrm{~m}$ at $T$ equals $1.5 \mathrm{~m}$, respectively. From the above settlement figures, it is observed that; constructing a new building beside the existing one has a great effect and may be exceed the allowable settlement. Only, if the distance between the two buildings becomes greater than $6 \mathrm{~m}$, the settlement will be in the safe side. 


\subsubsection{Con tact Pre ssure}

Figure (10) shows the contact pressure distribution along the common central axis of the two neighboring buildings with raft thickness $T$ of the new build ing $B_{R}$. It can be observed from this figure that: construction of the new building $B_{R}$ reduces the contact pressure of the existing build ing $B_{L}$ at the edges. At point $b$ which located at the far edge of the existing building $B_{L}$ the reduction ratio is equal to $56 \%$, while at point $g$ which located at the edge of the existing building $B_{L}$ near the new building $B_{R}$ this ratio is equal to $33.8 \%$ for $D$ equals $0.2 \mathrm{~m}$ and $T$ equals $1.5 \mathrm{~m}$. Increasing the distance $D$ between the two buildings $B_{L}$ and $B_{R}$ increases contact pressure at the far edge of the new building $B_{R}$.

\subsubsection{Moment}

Figure (11) shows the calculated moment distribution along the common central axis of the two neighboring buildings. The figure shows that; the moment at the centre of the existing building $B_{L}$ only has positive sign thus, the main reinforcements are located at the bottom of the existing building $B_{L}$. Due to construction of the new building $B_{R}$, the moment at the raft of the existing building $B_{L}$ reverses its sign into a negative sign.

Damages then could occur at the top of the existing building $B_{L}$ foundation. It could be concluded that not only the additional settlement due to constructing the new building $B_{R}$ causes damages for the existing one but also a reversed moment is generated as well. Increasing the separation distance $D$ between the two buildings decreases the induced additional negative moment of the existing build ing $B_{L}$.

At $D$ equals $6 \mathrm{~m}$, the bending moment of the existing building $B_{L}$ matches with moment of the existing building $B_{L}$ prior constructing the new building $B_{R}$ indicating no effect of construction in the existing one.

\subsection{Raft - Piled Raft Interaction}

This section presents the case of constructing the new building $B_{R}$ on piled raft where the existing building $B_{L}$ is resting on a raft [R-PR] system. Geometry and loads of the existing building $B_{L}$ and three different models of piled raft with three different pile spacing are considered in the analysis as shown in Figure (12). It should be noted that the piles used under the new building raft are friction piles constructed through and ending on the clay layer.

\subsubsection{Ranges of Parametric Study Variables}

Parametric study is carried out covering a wide range of foundation variables such as: pile spacing $S$, pile diameter $d$, pile length $L$, piled raft size $A \times B$ and the applied load $q$.

The effect of using piled raft as a foundation system of the new building $B_{R}$ on the existing building $B_{L}$ in PortSaid typical soil stratification, under various conditions and parameters are examined. Ranges of the numerical parameters are listed in Table 3.

Case studies are carried out to study effect of constructing the piled raft $B_{R}$ on the existing build ing $B_{L}$.

Figures (13) through (21) are presented to describe the effect of each variable on the settlement, differential settlement, contact pressure and bending moments of the existing build ing $B_{L}$ (raft foundation).

\subsubsection{Effect of Pile Length $L$}

Figure (13) shows the relation between the pile length $L$ in the piled raft $B_{R}$ and settlement ratio rsc of the existing building $B_{L}$. The figure shows that the influence of pile length $L$ in settlement reduction of the existing building $B_{L}$ starts at a pile length of $8 \mathrm{~m}$. Settlements may also decrease when pile length equals $8 \mathrm{~m}$. The reason is that the top surface of clay layers begins at a depth of about $8 \mathrm{~m}$. A practical piled raft used in settlement reduction in Port-Said is considered when pile length reaches $24 \mathrm{~m}$.

This length can reduce settlement of the existing building $B_{L}$ to about $21 \%$ of the calculated settlements for the case of raft-raft [R-R] system.

From Figure (14) it is noted that, increasing the pile length $L$ decreases the angular distortion ratio $\mathrm{r} \alpha$ of the existing build ing $B_{L}$. Optimal pile length $L$ ranges from 16 to $24 \mathrm{~m}$, where the reduction in the angular distortion ratio r $\alpha$ of the existing building $B_{L}$ ranges from 1 to 0.355 , respectively.

Figure (15) shows the relation between the contact pressure of the existing building $B_{L}$ and the pile length $L$ of piled raft $B_{R}$. The figure shows that, increasing the pile length $L$ decreases the contact pressure of the existing building $B_{L}$ and using of pile length $L$ equals $8 \mathrm{~m}$ is not effective.

Figure (16) shows the bending moment distribution along the common central axis of the existing building $B_{L}$ and piled raft $B_{R}$. from this figure it can be observed that; construction of the new building $B_{R}$ causes a negative mo ment that appears at the top of the existing building $B_{L}$.

This negative moment may causes damages on the top of the existing building $B_{L}$ foundations due to insufficient steel area. Increasing of the pile length $L$ decreases amount of negative moment that appears on the top of the existing building $B_{L}$ until it disappears at a pile length $L$ equals $24 \mathrm{~m}$.

\subsubsection{Effect of Pile Diameter d}

Figure (17) shows effect of pile diameter $d$ in piled raft $B_{R}$ on settlement ratio rsc of the existing building $B_{L}$. It illustrates that increasing the pile diameter $d$ did not affect the settlement of the existing building $B_{L}$. In addition, the increasing the pile diameter $d$ did not also affect the contact pressure and bending moment of the existing building $B_{L}$.

\subsubsection{Effect of Pile Spacing $S$}

Figure (18) shows the effect of the pile spacing ratio $S / d$ where $S$ is the pile spacing (m) and $d$ is the pile diameter (m), on the settlement ratio rsc of the existing building $B_{L}$. From this figure it is noted that decreasing pile spacing ratio $S / d$ decreases the computed settlement ratio of the existing build ing $B_{L}$.

It is suggested that the suitable pile spacing ranges from 2 to $3 \mathrm{~m}$. Results also shows that pile spacing slightly affects the contact pressure and bending moment at the raft foundation of the existing build ing $B_{L}$.

\subsubsection{Effect of Distance $D$}

Figure (19) shows the relation between the distance $D$, which is the distance between the two buildings and the angular distortion ratio r $\alpha$ of the existing building $B_{L}$. The 
distance $D$ is inversely proportional to angular distortion ratio $r \alpha$ of the existing building $B_{L}$. At $L$ equals to $16 \mathrm{~m}, d$ equals to $0.5 \mathrm{~m}$, the value of r $\alpha$ decrease from 1 to 0.4 for $D$ equals to $0.2,6 \mathrm{~m}$, respectively.

\subsection{Generalization Factors}

The analysis is performed on model building which has the same size for the existing building $B_{L}$ and piled raft $B_{R}$ of $20 \times 20 \mathrm{~m}^{2}$. Uniform load on the existing building $B_{L}$ equals $50 \mathrm{kN} / \mathrm{m}^{2}$ and for the piled raft $B_{R}$ the load is equal to $120 \mathrm{kN} / \mathrm{m}^{2}$. The diagram shown in Figure (20) presents generalization factors for loads of piled raft $B_{R}$, while Figure (21) illustrates the generalization factors for dimensions for the existing building $B_{L}$ and piled raft $B_{R}$.

Generalization factors are carried out for models of $10 \times 10 \mathrm{~m}^{2}$ and $15 \times 15 \mathrm{~m}^{2}$ for both raft and piled raft under uniform pressure of 120,180 and $240 \mathrm{kN} / \mathrm{m}^{2}$ for piled raft.

Values of settlements at specified nodes $a, d, f$ and $g$, differential settlements and bending moments of the existing building $B_{L}$ are presented. The corresponding value in the diagrams is multiplied by the appropriate estimated generalization factor.

\section{COMPARISON BETWEEN ALL SYSTEMS}

Mohamedien et al (2013) carried out a parametric study to examine the efficiency of constructing R.C. wall adjacent to an existing building to reduce the differential settlement of it. A comparison between R.C. wall and piled raft as settlement reducers was carried out in this paper using the results of [16].

Figure (22) shows comparis on between all the systems used to reduce the differential settlement of the existing building $B_{L}$ when the two buildings are located at nearly the same foundation level equals $1.9 \mathrm{~m}$ and distance between the two buildings $D$ equals $0.2 \mathrm{~m}$. The two buildings have the same raft size $20 \times 20 \mathrm{~m}^{2}$, and load of the existing building $B_{L}$ equals $50 \mathrm{kN} / \mathrm{m}^{2}$. The new building $B_{R}$ is loaded by a uniform pressure of $120 \mathrm{kN} / \mathrm{m}^{2}$. The differential settlement shows as a relative angular rotation of the existing building $B_{L}$.

Raft-raft interaction [R-R] is proposed as a reference used for relative angular rotation of $100 \%$. It illustrates that: using R.C. wall without anchor between the two buildings [R-W-R] of depths equal to 6,9 and $12 \mathrm{~m}$ reduces relative angular rotation of the existing building $B_{L}$ to 95,78 and $59 \%$, respectively. While, using anchored R.C. wall [R-AW-R] of depths equal to 6, 9, 12 and $15 \mathrm{~m}$ reduces relative angular rotation of the existing building $B_{L}$ to $60,51,48$ and $46 \%$. Then, anchored wall has been preferred to reduce relative angular rotation of the existing building $B_{L}$. The less wall depth is, the less the cost of construction is. Wall thickness does not affect performance of anchored R.C. wall as illustrated. [R-AW$\mathrm{R}]$ system is more efficient than [R-W-R] system.

Using of piled raft as a construction system of the new building $B_{R}$ [R-PR] is illustrated. From the figure it can observe that, optimal piled raft system is pile length $24 \mathrm{~m}$, pile diameter $0.5 \mathrm{~m}$ and pile spacing ranged from $2-3 \mathrm{~m}$.

Optimal piled raft system reduces relative angular rotation of the existing building $B_{L}$ to $21 \%$.
Solution of using piled raft is suitable as a system for the new building $B_{R}$ than using of the R.C wall between the two buildings. Cost of construction of the two systems could be very important to select the optimal system which could be used beneath the existing build ing $B_{L}$.

Also, taking the high cost of piled raft into consideration and that cost of pile casting depending on the soil condition, its diameter, lengths, driven or bored, mach ine or manmade and number of piles, all should be considered.

\section{CONCLUSIONS}

A parametric study is carried out to examine the efficiency of piled raft as a foundation system for a new building constructed adjacent to an existing one.

Comparis on between different systems of settlement reducers has been illustrated. These systems are: RaftRaft [R-R], Raft-Wall-Raft [R-W-R], Raft-Anchored Wall-Raft [R-AW-R] and Raft-Piled Raft [R-PR]. Using R.C. wall without anchor between the two buildings [RW-R] with depths equal to 6,9 and $12 \mathrm{~m}$, and with thickness $0.4 \mathrm{~m}$ reduces the relative angular rotation of the existing build ing to 95,78 and $59 \%$, respectively.

Using anchored wall [R-AW-R] with the same thickness and with depths $6,9,12$ and $15 \mathrm{~m}$ reduces the relative angular rotation of the existing building to 60,51 , 48 and $46 \%$, respectively. Piled raft is a suitable foundation system in Port- Said area compared with RaftRaft [R-R], Raft-Wall-Raft [R-W-R] and Raft-Anchored Wall-Raft [R-AW-R] systems. Different parameters of piled raft such as pile length, pile diameter, pile spacing, loading, raft dimensions and distance between the two buildings have been considered. Optimal piled raft dimensions can be used in Port-Said for the new building are those having $24 \mathrm{~m}$ pile length, $0.5 \mathrm{~m}$ pile diameter and $2-3 \mathrm{~m}$ pile spacing. Optimal piled raft reduces the computed relative angular rotation of the existing building about $21 \%$ of the Raft-raft foundation system.

\section{REFERENCES}

[1] Golder Associates (1979): "Geotechnical Report for Port-Said Area”, Port-Said, Egypt.

[2] Clancy, P., Randolph, M. (1993): "An approximate analysis procedure for piled raft foundations". International journal for numerical methods in geomechanics, 17:849-869.

[3] Poulos, H. (1994): "An approximate analysis of piledraft interaction", Int. Jour For Num. Method in Geomechanics , 18:73-92.

[4] Poulos H. (2001): "Methods of analysis of piled raft foundations", International Society of Soil Mechanics and Geotechnical Engineering, July.

[5] Young-Kyo S., Kyung-sik C. and Sung-Gyo J. (2003):"'Design Charts of Piled Raft Foundations on Soft Clay". International Offshore and Polar Engineering Conference, Honolulu, Hawaii, USA, May 2003. ISBN 1-880653-60-5 (Set); ISSN 10986189 (Set).

[6] El Gendy M., Hanish J. ,Kany M. (2006): “Empirical nonlinear analys is of piled raft", Bautechnik 83 Heft 9 Ernst \& Sohn, Berlin. 
[7] Small J.C. and Poulos H.G. (2006): "Non-Linear Analysis of Piled Raft Foundations". GSP 158 Contemporary Issues in Deep Foundations.

[8] Kany M., EL Gendy M., EL Gendy A. (2007): "Analysis and design of slab foundation-Program ELPLA" GEOTEC Software, Zirndorf, Germany.

[9] El Gendy M. (2007): "Formulation of a composed coefficient technique for analyzing large piled raft", Scientific Bulletin, Faculty of Engineering, Ain Shams University, Cairo, Egypt. Vol. 42, No. 1, March, pp. 29-56.

[10] El Gendy M. (2007): "Deriving equations for analyzing friction piles in clay soil", Scientific Bulletin, Faculty of Engineering, A in Shams University, Cairo, Egypt. Vol. 42.

[11] Chow H. (2007):“'Analysis of Piled-Raft Foundations with Piles of Different Lengths and Diameters". A thesis submitted for the Degree of Doctor of Philosophy in the University of Sydney. August 2007.

[12] Reda A.(2009):“Optimization of Piled Raft in PortSaid”. A Thesis Submitted in Partial Fulfillment of the Requirement for the Degree of Master of Science in Civil Engineering.

[13] Zhang Z., Huang C. and Zhang Z. (2009): "Simplified Nonlinear Analysis Methods for Vertically Loaded Piles and Piled Raft In Layered Soil". EJGE, Vol. 14, Bund.k.

[14] Singh A.K. and Singh A.N. (2011):" Experimental Study of Piled Raft Foundation". Proceedings of Indian Geotechnical Conference. December 15-17, 2011, Kochi (Paper No D-378).

[15] Kitiyodom P., Matsumoto T. and Sonoda R. (2011): "Approximate Numerical Analysis of A Large Piled Raft Foundation". SOILS AND FOUNDATIONS Japanese Geotechnical Society. Vol. 51, No. 1, 1-10 Feb.2011.

[16] Mohamedien M., El Gendy M., El Arabi I., El Azab M., Moubarak A., (2013):'Reducing Settlement Using Retaining Walls for Neighboring Foundations in Port-Said". Port-Said Engineering Research Journal, Faculty of Engineering, Suez Canal University, Vol.17, No.2, Sep.2013.

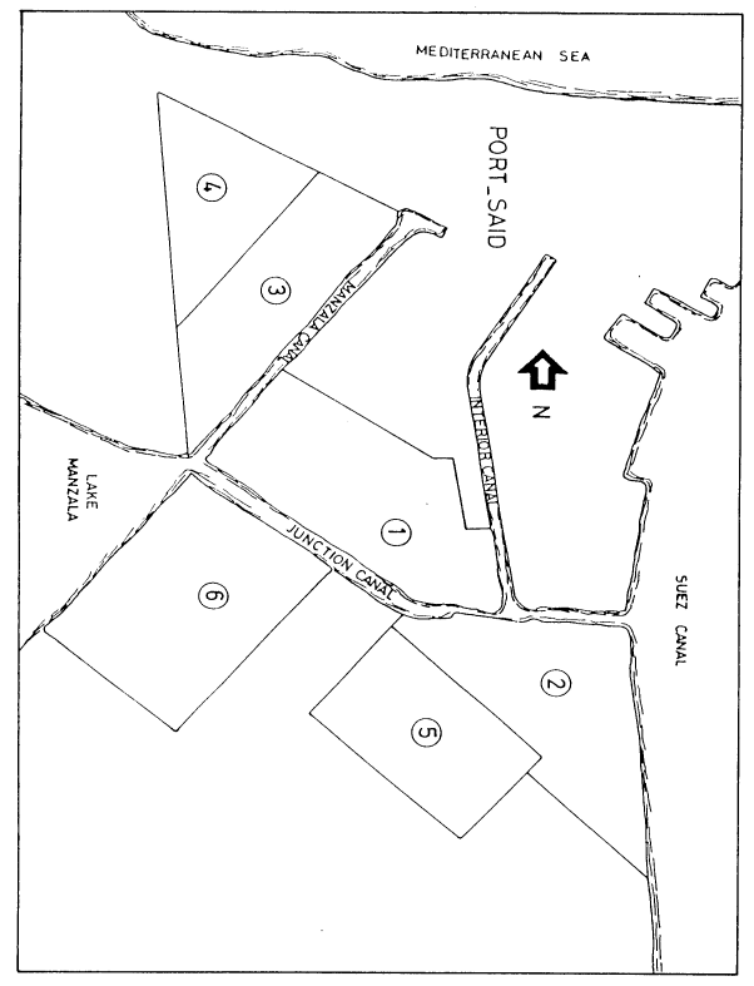

Figure 1: Port-Said zones 


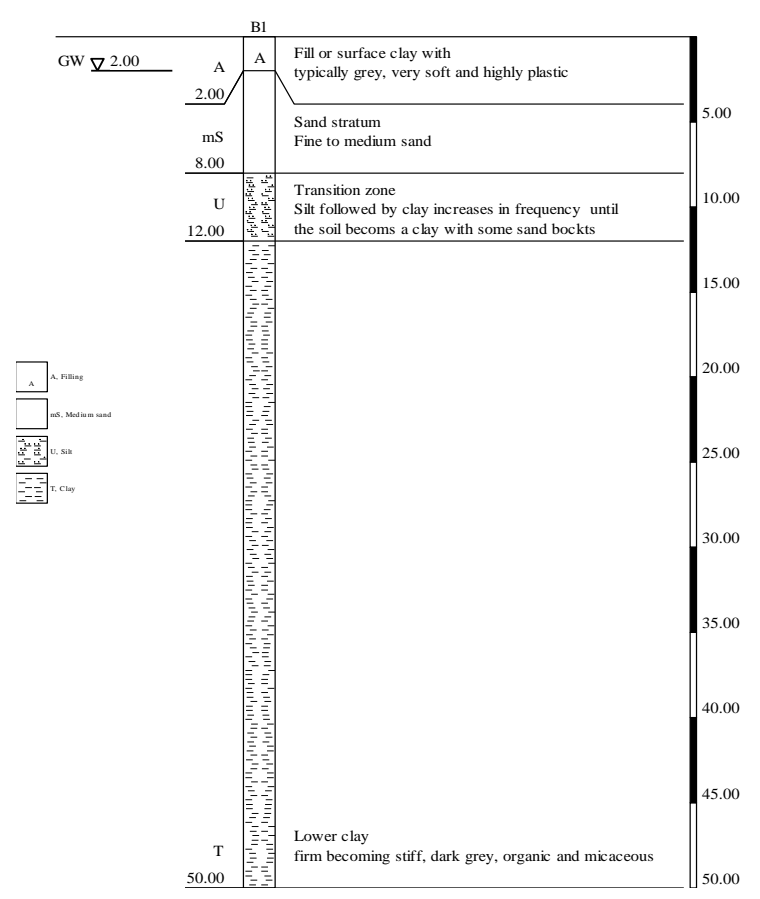

Figure 2: Main soil pr ofile of Port-Said
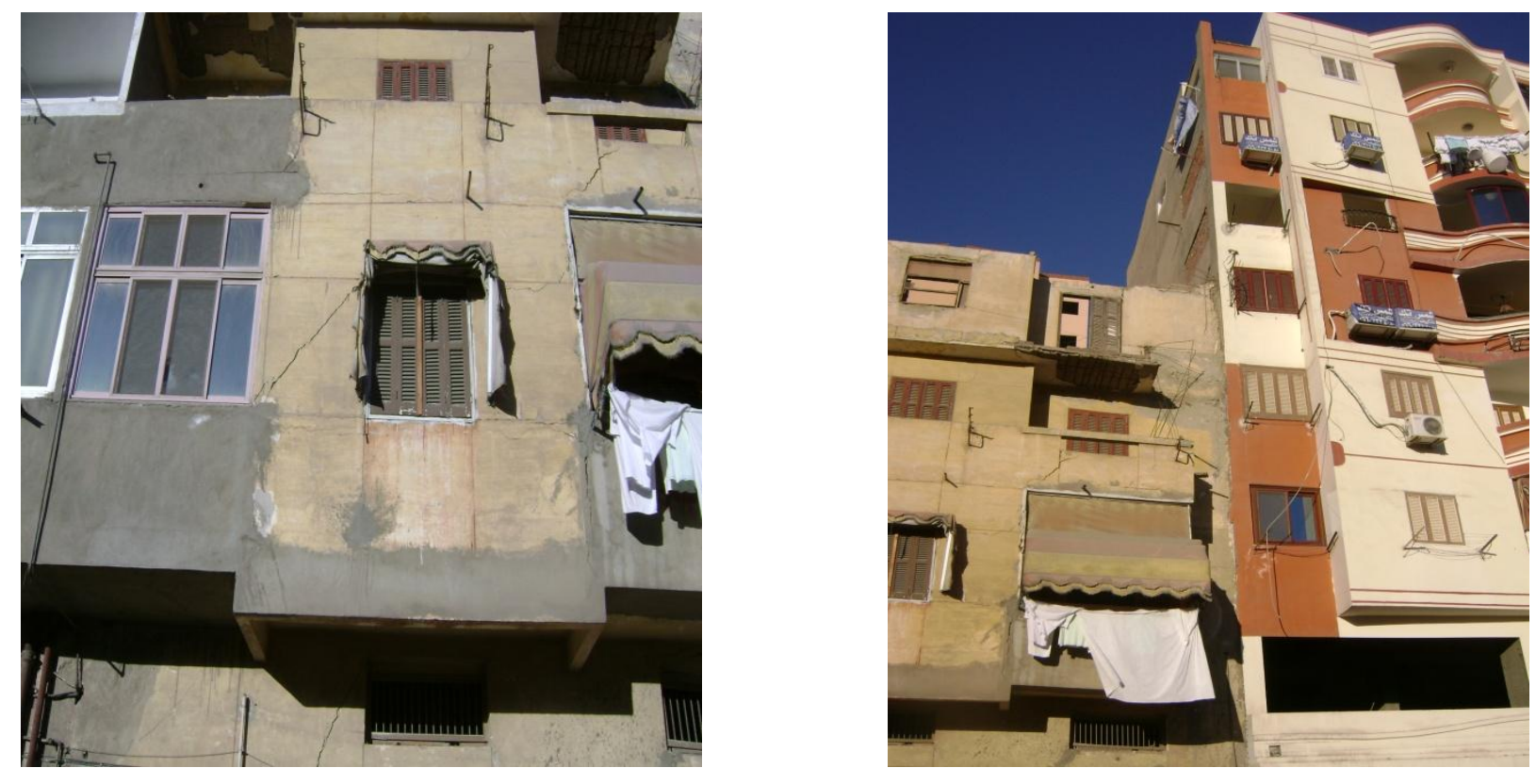

Figure 3: Damages resulting from adjacent construction

Table 1.Typical soil parameters

\begin{tabular}{|c|c|c|c|c|c|c|}
\hline $\begin{array}{l}\text { Layer } \\
\text { No. }\end{array}$ & Type of soil & $\begin{array}{l}\text { Depth under } \\
\text { the ground } \\
\text { Surface } \\
\mathrm{z}(\mathrm{m})\end{array}$ & $\begin{array}{l}\text { Modulus of } \\
\text { Compressibility } \\
\text { Es }\left(\mathrm{kN} / \mathrm{m}^{2}\right)\end{array}$ & $\begin{array}{l}\text { Undrained } \\
\text { cohesion } \\
c_{u}\left(\mathrm{kN} / \mathrm{m}^{2}\right)\end{array}$ & $\begin{array}{l}\text { Poisson's } \\
\text { ratio of the } \\
\text { soil } \\
v_{s}(-)\end{array}$ & $\begin{array}{l}\text { Unit } \\
\text { weight of } \\
\text { the soil } \\
\gamma_{s}\left(\mathrm{kN} / \mathrm{m}^{3}\right)\end{array}$ \\
\hline 1 & Fill or surface clay & 1.9 & 1750 & - & \multirow{4}{*}{$\begin{array}{l}0.3 \text { for sand } \\
0.45 \text { for clay }\end{array}$} & $\gamma_{s}=18$ \\
\hline 2 & Sand & 8.3 & 60000 & - & & $\gamma_{\mathrm{sub}}=8$ \\
\hline 3 & Silt & 12.0 & 6500 & - & & $\gamma_{\mathrm{sub}}=8$ \\
\hline 4 & Clay & 41.5 & Eq. 1 & Eq. 2 & & $\gamma_{\mathrm{sub}}=8$ \\
\hline
\end{tabular}


Table 2. Ranges of variables for the new raft

\begin{tabular}{|l|l|}
\hline Name of variables & Range \\
\hline Raft thic kness of the new building $T,(\mathrm{~m})$ & $0.8,1.0,1.2,1.5$ \\
\hline Distance between two buildings $D,(\mathrm{~m})$ & $0.2-2.0-4.0-6.0$ \\
\hline Foundation size $A \times B,\left(\mathrm{~m}^{2}\right)$ & $10 \times 10,15 \times 15,20 \times 20$ \\
\hline Applied load for the new building $q,\left(\mathrm{kN} / \mathrm{m}^{2}\right)$ & $120,180,240$ \\
\hline
\end{tabular}

Table 3. Ranges of variables for the piled raft

\begin{tabular}{|l|l|}
\hline Name of variables & Range \\
\hline Pile length $L,(\mathrm{~m})$ & $8,16,24$ \\
\hline Pile diameter $d,(\mathrm{~m})$ & $0.4,0.5,0.6$ \\
\hline Pile spacing $S .(\mathrm{m})$ & $2,3,4$ \\
\hline Foundation size $A \times B,\left(\mathrm{~m}^{2}\right)$ & $10 \times 10,15 \times 15,20 \times 20$ \\
\hline Applied load $q,\left(\mathrm{kN} / \mathrm{m}^{2}\right)$ & $120,180,240$ \\
\hline
\end{tabular}
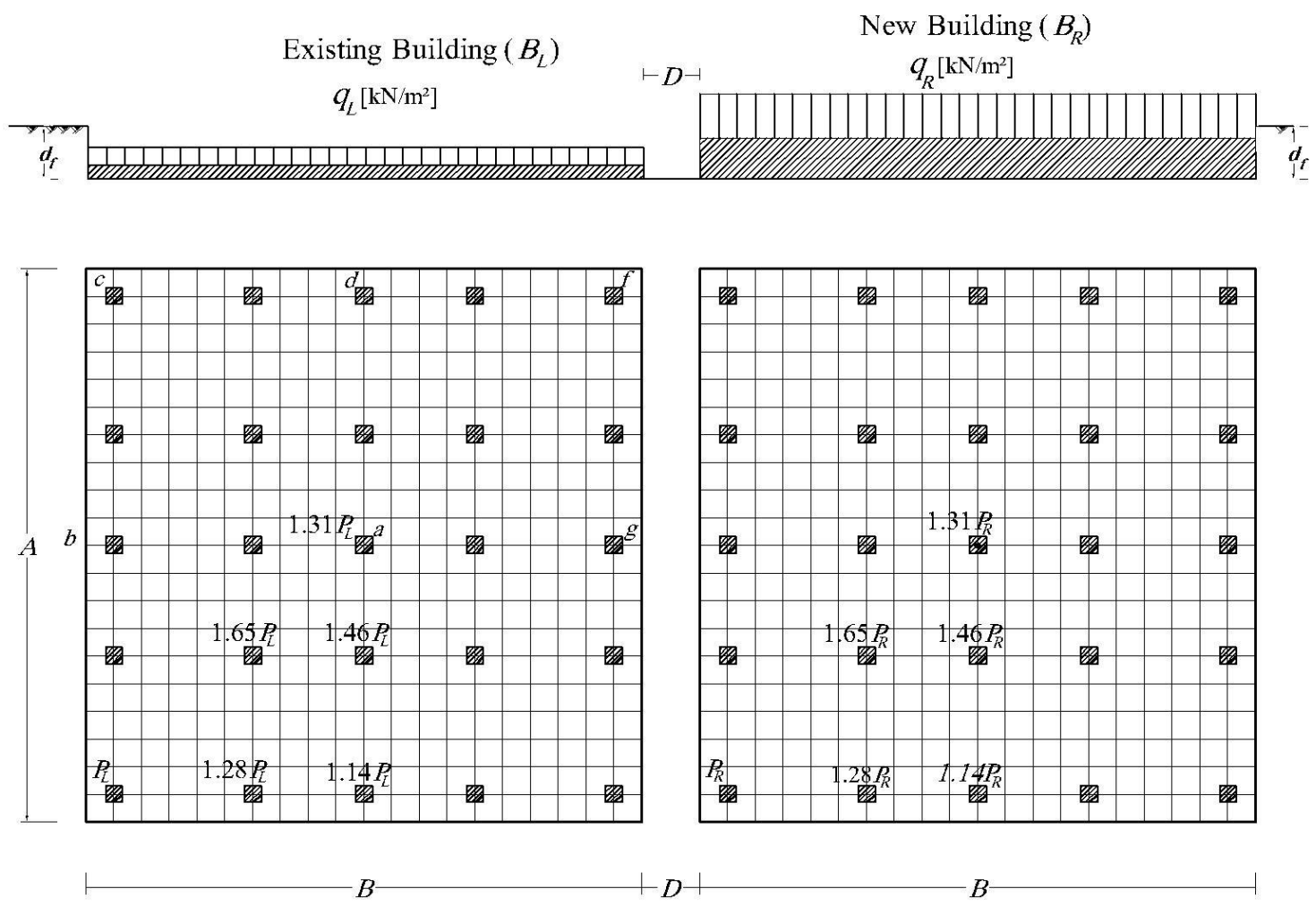

Distance between the two buildings $(D)=0.2,2,4,6[\mathrm{~m}]$

$q_{L}=50\left[\mathrm{kN} / \mathrm{m}^{2}\right] \quad q_{R}=120,180,240\left[\mathrm{kN} / \mathrm{m}^{2}\right]$

$P_{L}=614.44[\mathrm{kN}] \quad P_{R}=1474.65[\mathrm{kN}]$

Figure 4: Rafts geometry and loads for buildings $B_{R}$ and $B_{L}$ 


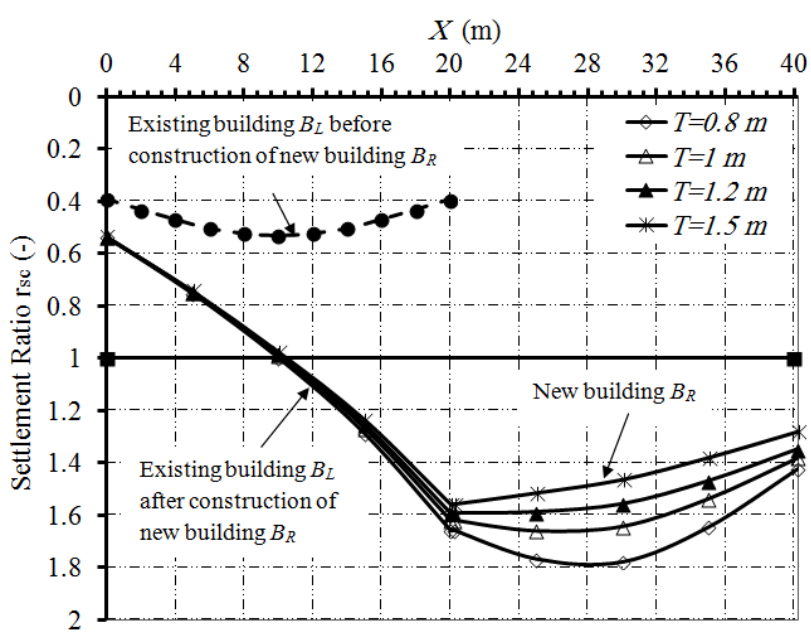

Figure 5: Settlement ratio of two buildings, $D=0.2 \mathrm{~m}$

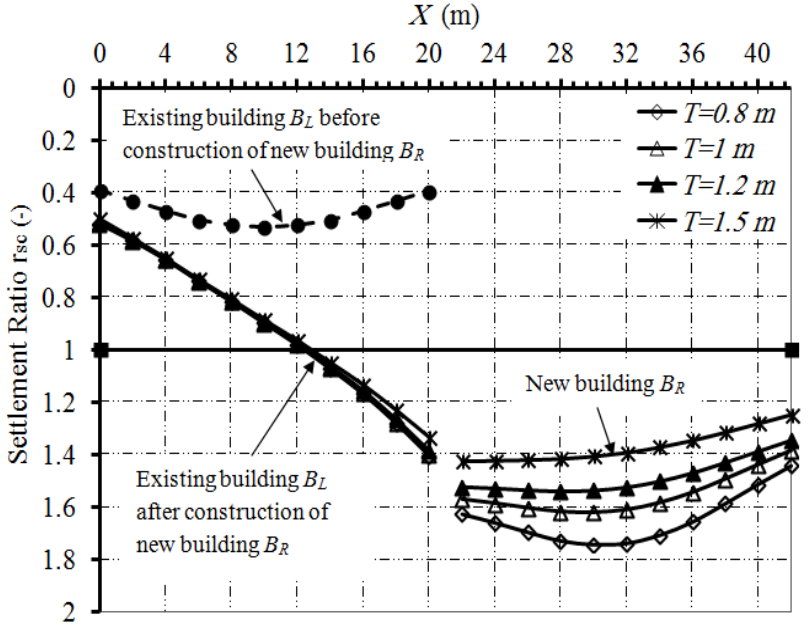

Figure 6: Settlement ratio of two buildings, $D=2 \mathrm{~m}$

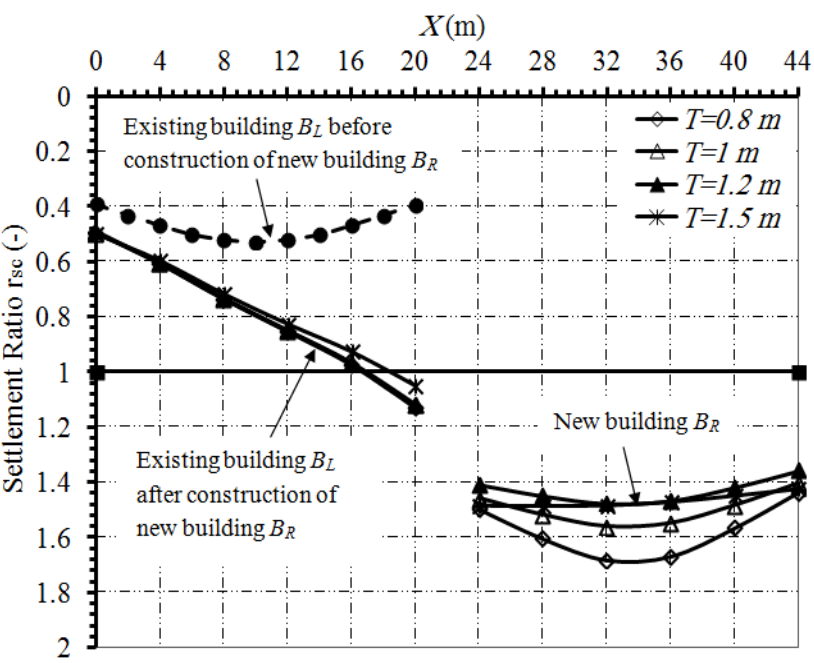

Figure 7: Settlement ratio of two buildings, $D=4 \mathrm{~m}$

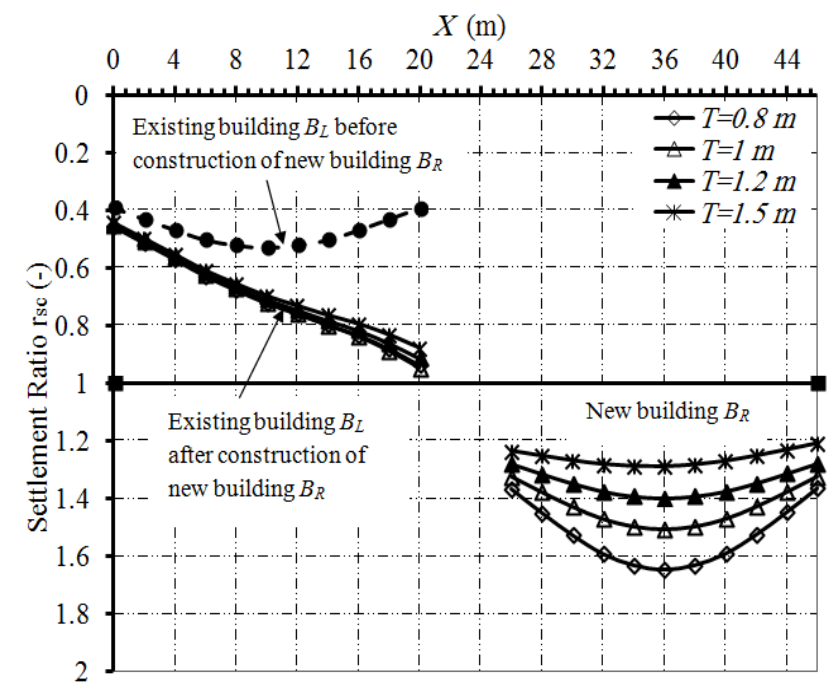

Figure 8: Settlement ratio of two buildings, $D=6 \mathrm{~m}$

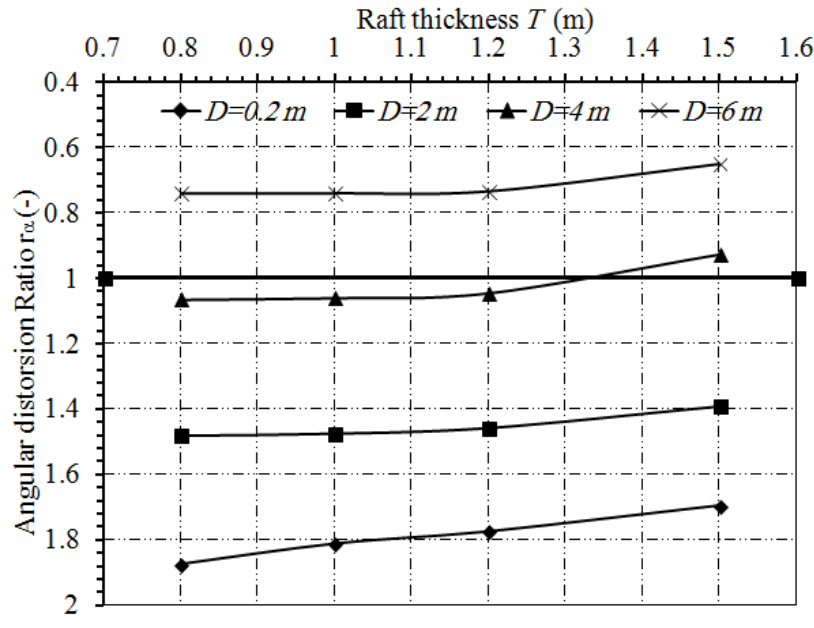

Figure 9: Angular distortion ratio ro of the existing buil ding $B_{L}$ at different values of $D$

$X(\mathrm{~m})$

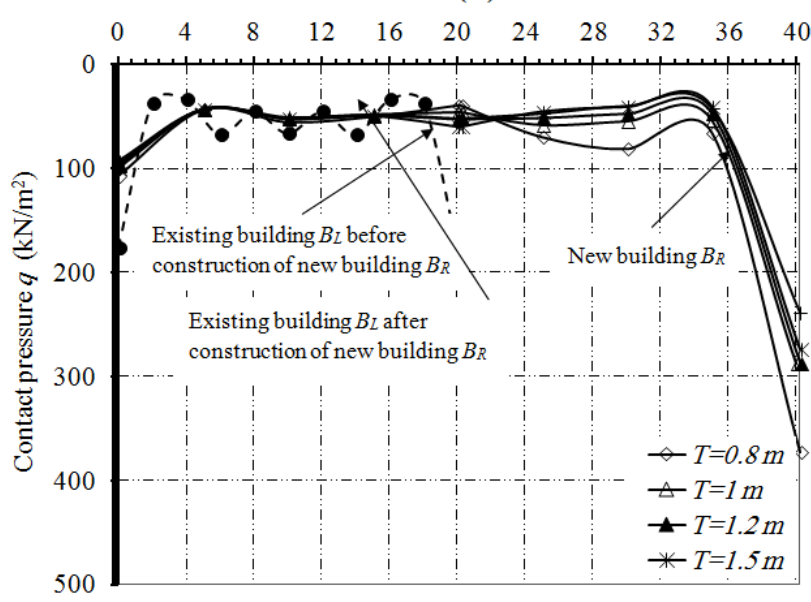

Figure 10: Contact pressure of two buildings, $D=0.2 \mathrm{~m}$ 
$X(\mathrm{~m})$

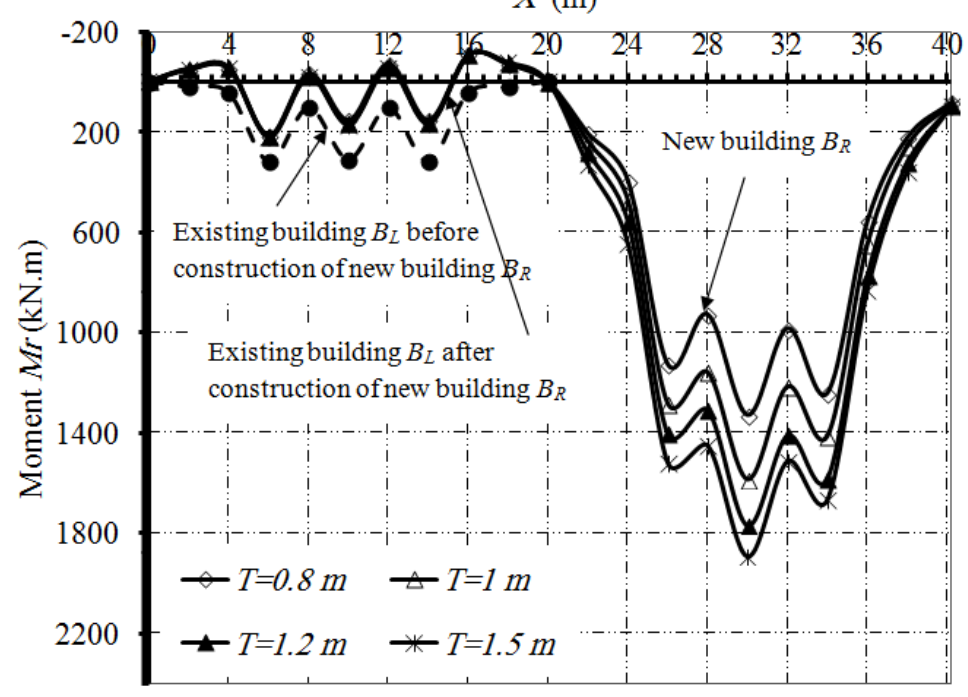

Figure 11: Bending moment of two buildings, $D=0.2 \mathrm{~m}$
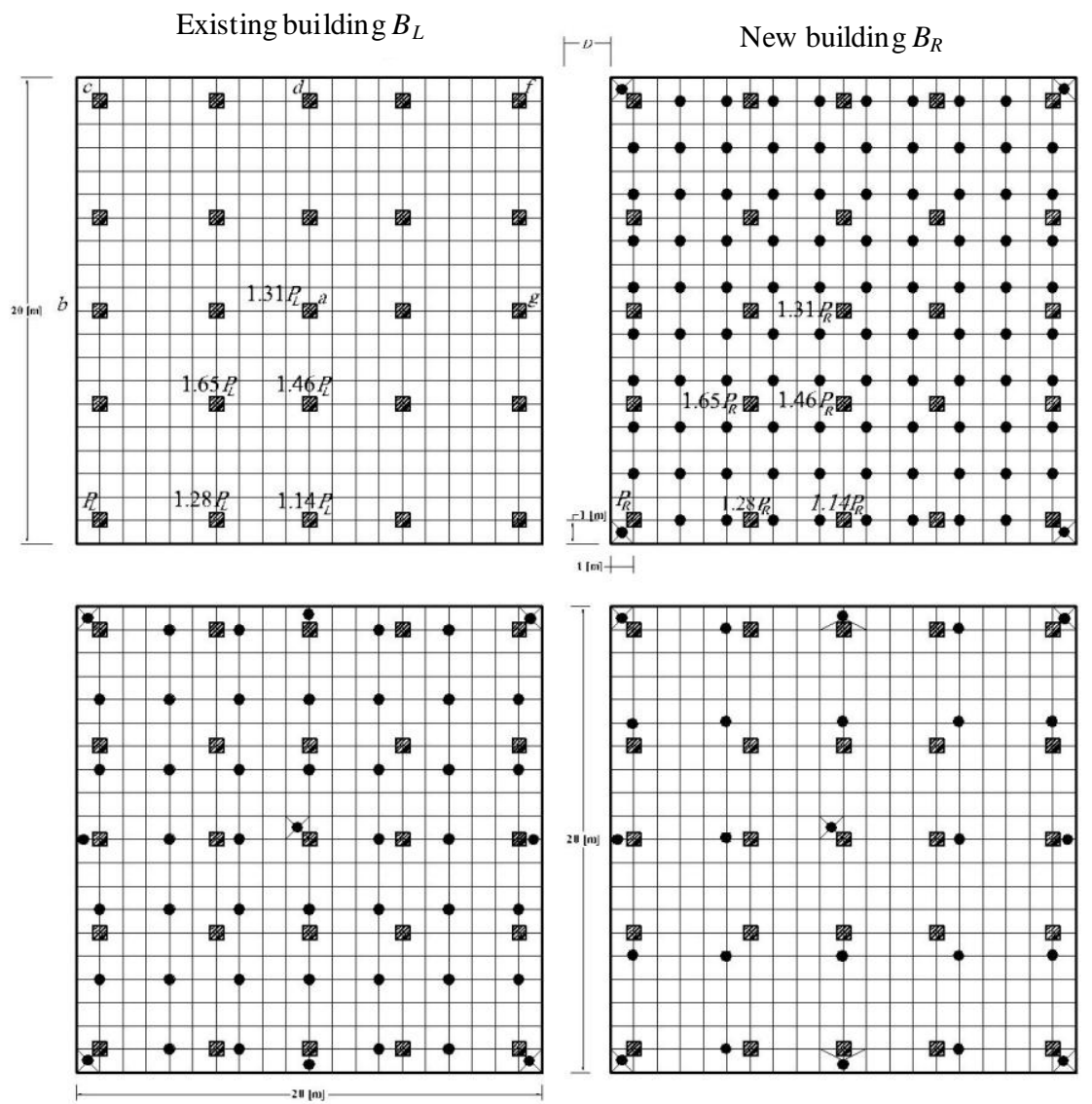

Piled raft $3 \mathrm{~m}$ spacing

Piled raft $4 \mathrm{~m}$ spacing

Figure 12: Raft and piled raft models 
$D=0.2 \mathrm{~m}, d=0.5 \mathrm{~m}, S=2 \mathrm{~m}$ $X(\mathrm{~m})$

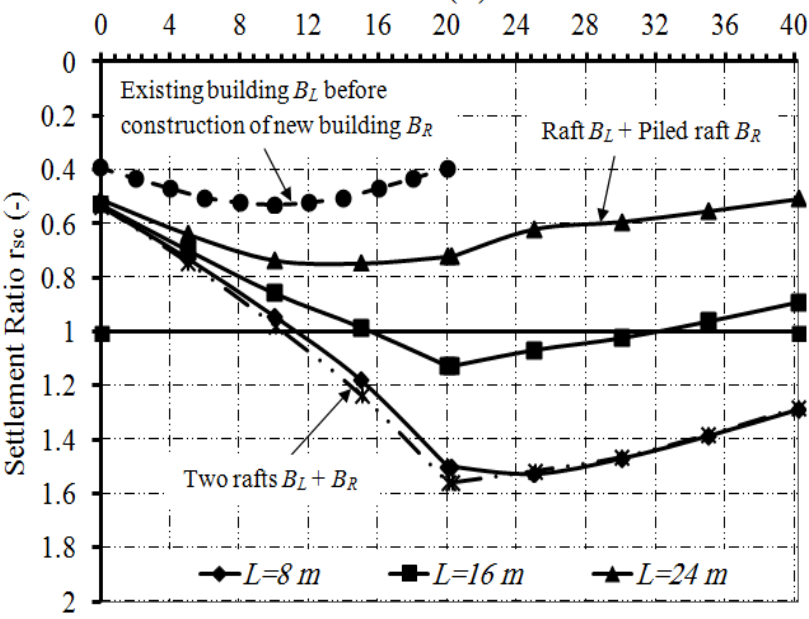

Figure 13: Effect of pile length $L$ on settlement ratio rsc of the existing building $B_{L}$

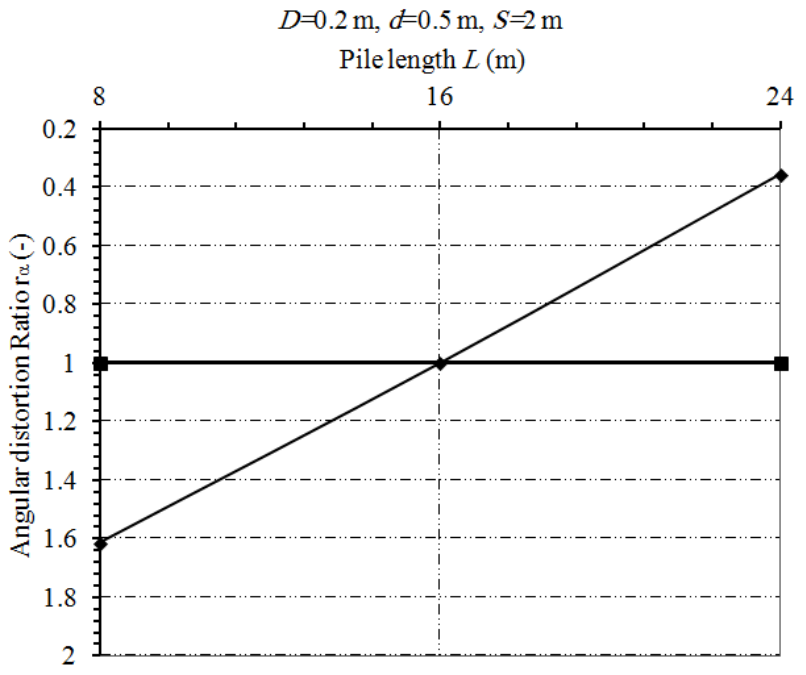

Figure 14: Effect of pile length $L$ on angular distor tion ratio ro

$D=0.2 \mathrm{~m}, d=0.5 \mathrm{~m}, S=2 \mathrm{~m}$ $X(\mathrm{~m})$

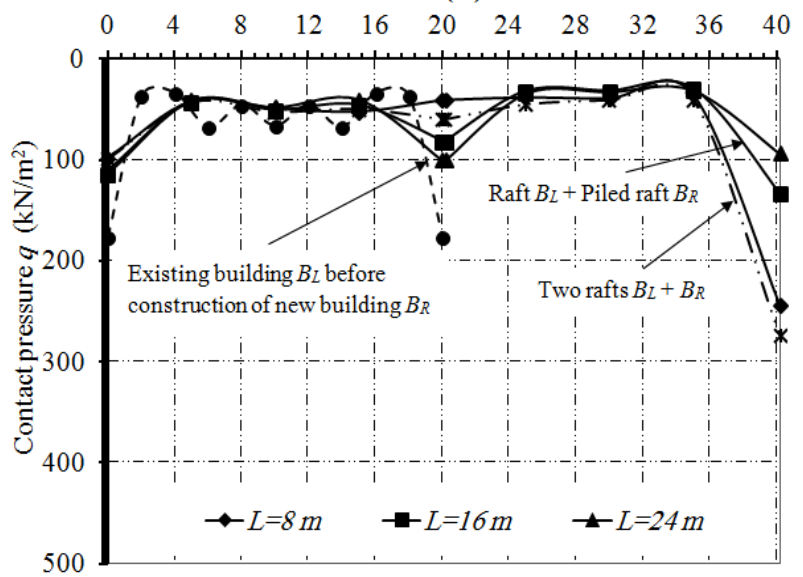

Figure 15: Effect of pile length $L$ on contact pressure $q$ of the existing building $B_{L}$

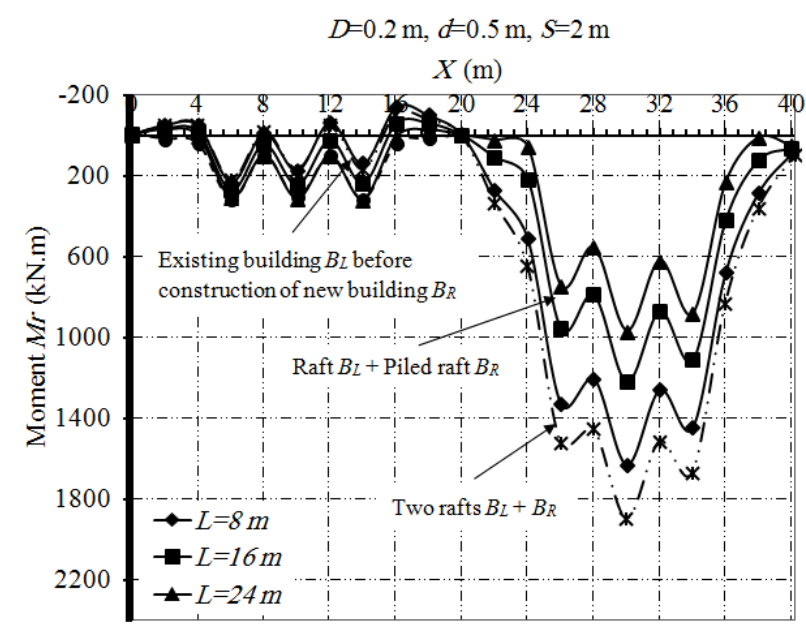

Figure 16: Effect of pile length $L$ on moment $M r$ of the existing buil ding $B_{L}$

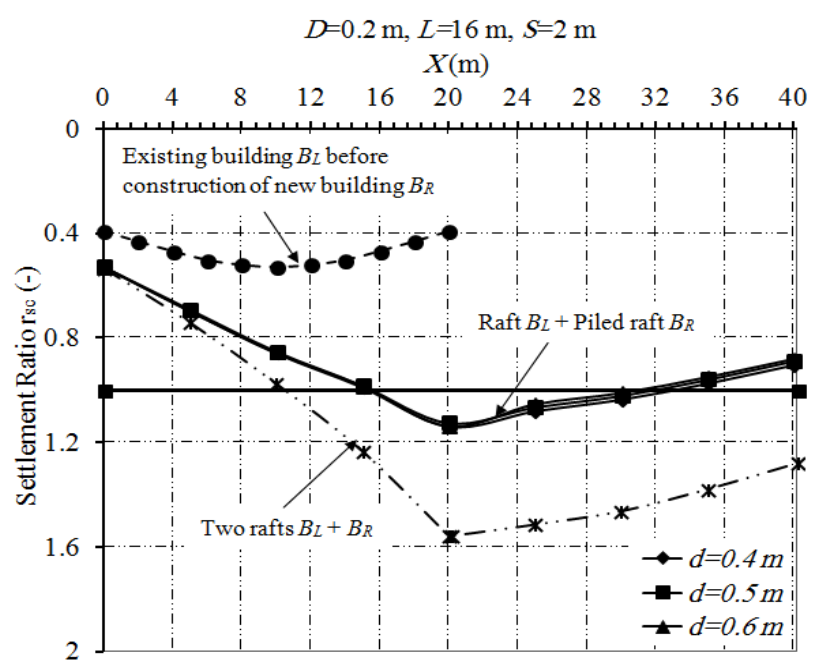

Figure 17: Effect of pile diameter $d$ on settlement ratio rsc of the existing building $B_{L}$ $D=0.2 \mathrm{~m}, L=16 \mathrm{~m}, d=0.5 \mathrm{~m}$

$$
X(\mathrm{~m})
$$

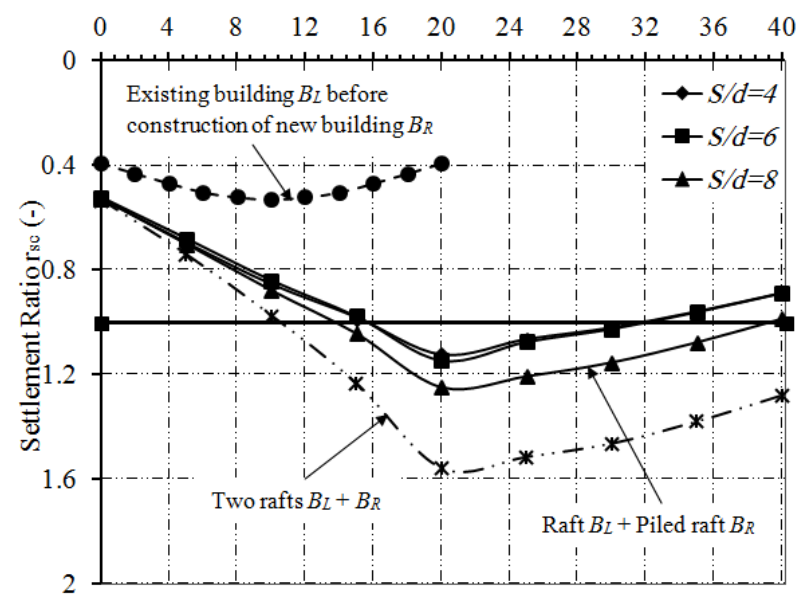

Figure 18: Effect of pile s pacing ratio $S / d$ on the settlement ratio rsc of the existing building $B_{L}$ 
$d=0.5 \mathrm{~m}, S=2 \mathrm{~m}$

Pile length $L(\mathrm{~m})$

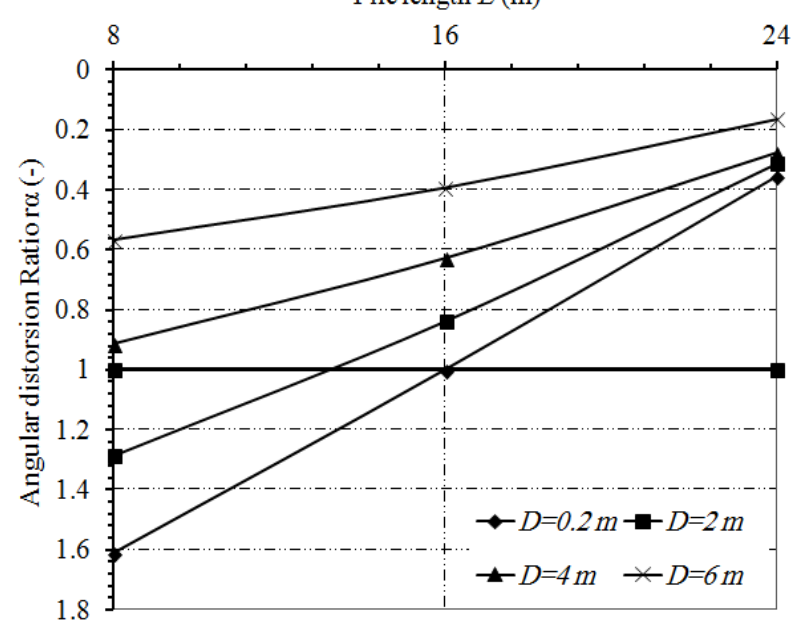

Figure 19: Effect of distance between the two buil dings $D$ on ang ular distortion ratio r $\alpha$

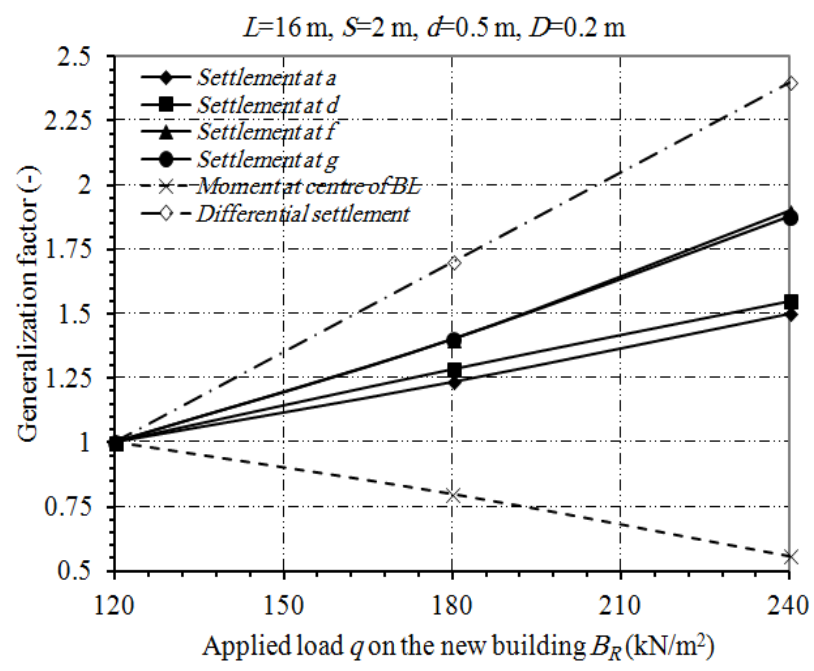

Figure 20: Generalization factors for piled raft loads

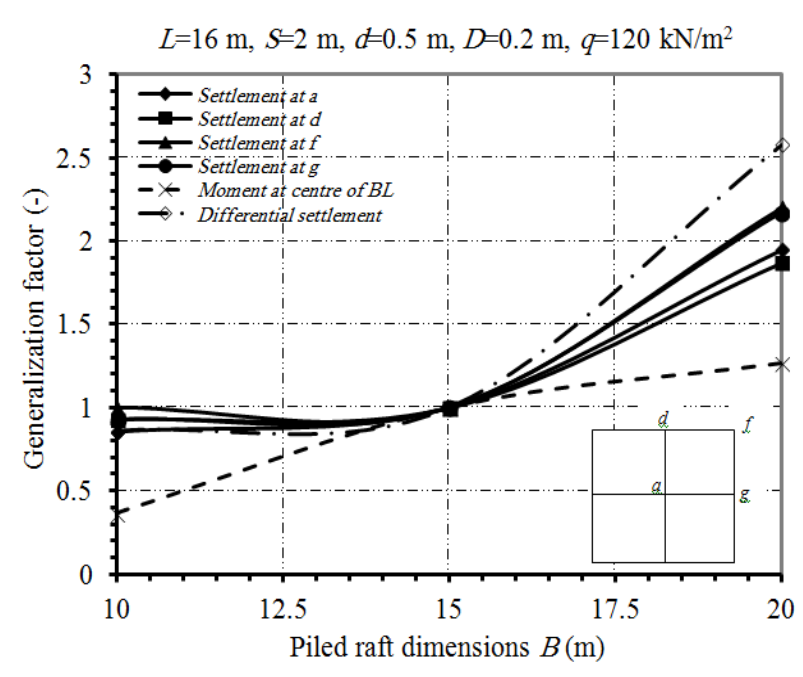

Figure 21 Generalization factors for piled raft dimensions

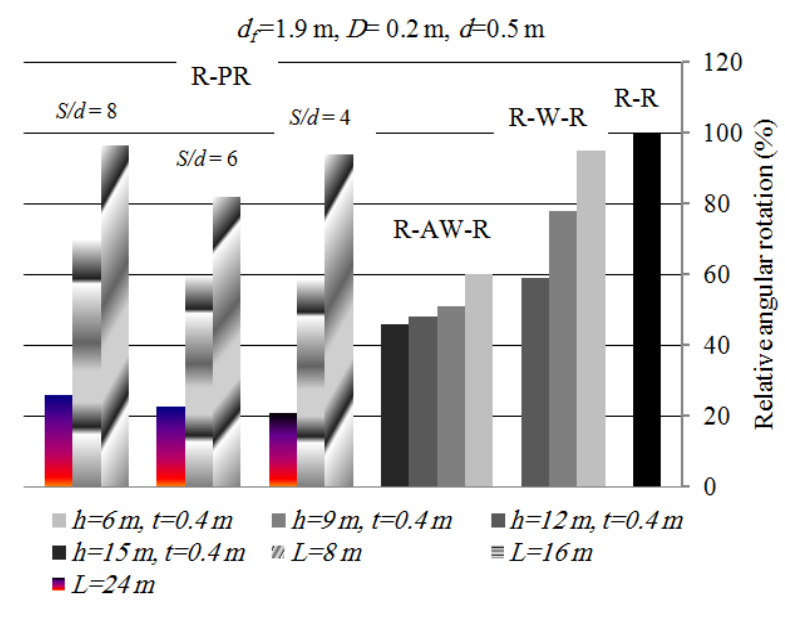

Figure 22: Relative angular relation (\%) between alternati ves for different settlement reducers 